Article

\title{
A Structural and Spectroscopic Study of the First Uranyl Selenocyanate, $\left[\mathrm{Et}_{4} \mathrm{~N}_{3}\left[\mathrm{UO}_{2}(\mathrm{NCSe})_{5}\right]\right.$
}

\author{
Stefano Nuzzo, Michelle P. Browne, Brendan Twamley, Michael E. G. Lyons and Robert J. Baker * \\ School of Chemistry, Trinity College, University of Dublin, 2 Dublin, Ireland; nuzzos@tcd.ie (S.N.); \\ Brownm6@tcd.ie (M.P.B.); twamleyb@tcd.ie (B.T.); melyons@tcd.ie (M.E.G.L.) \\ * Correspondence: bakerrj@tcd.ie; Tel.: +353-1-896-3501; Fax: +353-1-671-2826 \\ Academic Editors: Stephen Mansell and Steve Liddle \\ Received: 30 October 2015; Accepted: 4 February 2016; Published: 16 February 2016
}

\begin{abstract}
The first example of a uranyl selenocyanate compound is reported. The compound $\left[\mathrm{Et}_{4} \mathrm{~N}_{3}\left[\mathrm{UO}_{2}(\mathrm{NCSe})_{5}\right]\right.$ has been synthesized and fully characterized by vibrational and multinuclear $\left({ }^{1} \mathrm{H},{ }^{13} \mathrm{C}\left\{{ }^{1} \mathrm{H}\right\}\right.$ and $\left.{ }^{77} \mathrm{Se}\left\{{ }^{1} \mathrm{H}\right\}\right)$ NMR spectroscopy. The photophysical properties have also been recorded and trends in a series of uranyl pseudohalides discussed. Spectroscopic evidence shows that the U-NCSe bonding is principally ionic. An electrochemical study revealed that the reduced uranyl(V) species is unstable to disproportionation and a ligand based oxidation is also observed. The structure of $\left[\mathrm{Et}_{4} \mathrm{~N}\right]_{4}\left[\mathrm{UO}_{2}(\mathrm{NCSe})_{5}\right][\mathrm{NCSe}]$ is also presented and Se $\cdots \mathrm{H}-\mathrm{C}$ hydrogen bonding and Se $\cdots$ Se chalcogen-chalcogen interactions are seen.
\end{abstract}

Keywords: uranyl; structural determination; photophysics

\section{Introduction}

The chemistry of uranium in its highest oxidation state has held scientists fascination for a long period of time. The uranyl moiety, $\left[\mathrm{UO}_{2}\right]^{2+}$, is well studied in aqueous phases due, in part, to relevance in the nuclear waste treatment. Moreover, the photophysical properties of uranyl were first used in ancient roman times in colored glass [1], whilst comprehensive understanding of the bonding, and therefore photophysical properties, has come from both experiment and theory. An authoritative review by Denning summarizes these fundamental developments [2], and further reviews cover recent results [3-6]. The photophysical properties of the uranyl ion have been elucidated from these studies and the optical properties are due to a ligand-to-metal charge transfer (LMCT) transition involving promotion of an electron from a bonding -yl oxygen orbital $\left(\sigma_{\mathrm{u}}, \sigma_{\mathrm{g}}, \pi_{\mathrm{u}}\right.$ and $\left.\pi_{\mathrm{g}}\right)$ to a non-bonding $5 \mathrm{f}_{\delta}$ and $5 f_{\phi}$ orbital on uranium. De-excitation of this ${ }^{3} \Pi_{u}$ triplet excited state causes the characteristic green emission at $c a .500 \mathrm{~nm}$. Visible on the absorption and emission bands are the vibronic progression arising from strong coupling of the ground state Raman active symmetric vibrational $\mathrm{O}=\mathrm{U}=\mathrm{O}\left(v_{1}\right)$ mode with the ${ }^{3} \Pi_{u}$ electronic triplet excited state. Time resolved studies allow sometimes complex speciation in water to be deconvoluted [7], whilst in non-aqueous media the positions of the emission maxima and lifetimes can be used as electronic and structural probes. For instance in the family of complexes trans-[ $\left.\mathrm{UO}_{2} \mathrm{X}_{2}\left(\mathrm{O}=\mathrm{PPh}_{3}\right)_{2}\right](\mathrm{X}=\mathrm{Cl}, \mathrm{Br}, \mathrm{I})$ the photoluminescent properties do not vary [8], but for the compounds trans- $\left[\mathrm{UO}_{2} \mathrm{Cl}_{2} \mathrm{~L}_{2}\right]\left(\mathrm{L}=\mathrm{Ph}_{3} \mathrm{P}=\mathrm{NH}, \mathrm{Ph}_{3} \mathrm{P}=\mathrm{O}\right.$ and $\left.\mathrm{Ph}_{3} \mathrm{As}=\mathrm{O}\right)$ a red shift in the $\mathrm{O}_{\mathrm{yl}} \rightarrow \mathrm{U}$ LMCT band is observed, in line with the increased donor strength of the ligand [9]. A further interesting photophysical property of certain uranyl compounds are thermochromic effects. Thus the compound $\left[\mathrm{C}_{4} \mathrm{mim}_{3}\left[\mathrm{UO}_{2}(\mathrm{NCS})_{5}\right]\left(\mathrm{C}_{4} \mathrm{mim}=1\right.\right.$-butyl-3-methylimidazolium $)$ is thermochromic in ionic liquids [10] but in organic solvents $\left[\mathrm{Et}_{4} \mathrm{~N}_{3}\left[\mathrm{UO}_{2}(\mathrm{NCS})_{5}\right]\right.$ is not [11]. We have reported on the latter compound recently and now extend our study to the selenocyanate [NCSe] ${ }^{-}$ derivatives which have not been reported. Indeed there is only one structurally characterized U-NCSe 
complex, viz. $\left[\mathrm{Pr}_{4} \mathrm{~N}\right]_{4}\left[\mathrm{U}(\mathrm{NCSe})_{8}\right]$ [12]. In this work we have synthesized $\left[\mathrm{Et}_{4} \mathrm{~N}_{3}\left[\mathrm{UO}_{2}(\mathrm{NCSe})_{5}\right]\right.$ and have characterized this by vibrational and multinuclear NMR spectroscopy and a photophysical investigation. X-ray diffraction of the compound $\left[\mathrm{Et}_{4} \mathrm{~N}_{4}\left[\mathrm{UO}_{2}(\mathrm{NCSe})_{5}\right][\mathrm{NCSe}]\right.$ is also reported.

\section{Results and Discussion}

The synthesis of $\left[\mathrm{Et}_{4} \mathrm{~N}_{3}\left[\mathrm{UO}_{2}(\mathrm{NCSe})_{5}\right], \mathbf{1}\right.$, was conducted in a comparable way to that for the thiocyanate derivatives. Thus uranyl nitrate was treated with five equivalents of K[NCSe] followed by three equivalents of $\mathrm{Et}_{4} \mathrm{NCl}$ in acetonitrile. A yellow precipitate was formed which was soluble in dichloromethane or acetone. We have noted that whilst this compound is air and moisture stable, it is somewhat light sensitive so reactions were conducted in the dark; the uranium(IV) compound $\left[{ }^{n} \mathrm{Pr}_{4} \mathrm{~N}\right]_{4}\left[\mathrm{U}(\mathrm{NCSe})_{8}\right]$ was also reported to be light sensitive [12]. Decomposition to red selenium powder was sometimes observed but the fate of the uranium was not determined. An alternative route to this compound was to treat a THF solution of $\left[\mathrm{UO}_{2} \mathrm{Cl}_{2}(\mathrm{THF})_{3}\right]$ sequentially with K[NCSe] and $\mathrm{Et}_{4} \mathrm{NCl}$. 1 was characterized by spectroscopic methods and single crystals were grown from slow evaporation of an acetonitrile solution. Unfortunately, crystals grown from different solvents always proved to be twinned so refinement to a satisfactory standard was not possible, however it did prove atom connectivity (Figure S1). During the course of one experiment, a few single crystals which had a different morphology were observed; these were separated by hand and the structure was solved to be $\left[\mathrm{Et}_{4} \mathrm{~N}_{4}\left[\mathrm{UO}_{2}(\mathrm{NCSe})_{5}\right][\mathrm{NCSe}], \mathbf{2}\right.$.

The solid state structure of $\mathbf{2}$ is shown in Figure 1 and the packing shown in Figure 2. The structure of 2 contains disorder in two of the $\mathrm{Et}_{4} \mathrm{~N}^{+}$cations and the uncoordinated [NCSe] ${ }^{-}$anion which were modelled with restraints and constraints. The geometry around the uranyl in $\mathbf{2}$ are a typical pentagonal bipyramid with linear NCSe fragments and the $\mathrm{N} \cdots \mathrm{N}$ intramolecular distances are similar to that seen in $\left[\mathrm{Et}_{4} \mathrm{~N}_{3}\left[\mathrm{UO}_{2}(\mathrm{NCS})\right]_{5}(2: 2.89 \AA\right.$; NCS: $2.87 \AA$ ) [13]. The $\mathrm{U}=\mathrm{O}$ bond length is $1.771(2) \AA$ and average $\mathrm{U}-\mathrm{N}, \mathrm{N}=\mathrm{C}$ and $\mathrm{C}=\mathrm{Se}$ bond lengths of $2.459 \AA, 1.149 \AA$ and $1.794 \AA$ respectively can be compared to the uncoordinated $[\mathrm{N}=\mathrm{C}=\mathrm{Se}]^{-}$ion $(\mathrm{N}=\mathrm{C}: 1.081(14) \AA$ and $\mathrm{C}=\mathrm{Se}: 1.846(7) \AA)$ in 2. Upon coordination to the uranyl ion the $\mathrm{N}=\mathrm{C}$ bond lengthens slightly and the $\mathrm{C}=\mathrm{Se}$ bond shortens slightly, suggesting a reorganization in the $\pi$-framework of the ligand; this effect has also been observed in uranyl thiocyanates experimentally and theoretically $[11,14]$. The average $\mathrm{U}-\mathrm{N}$ bond in $\left[\mathrm{Et}_{4} \mathrm{~N}_{3}\left[\mathrm{UO}_{2}(\mathrm{NCS})\right]_{5}\right.$ is $2.443 \AA$ [13], whilst in a suite of [pyridinium] $\left[\mathrm{UO}_{2}(\mathrm{NCS})_{4}\left(\mathrm{H}_{2} \mathrm{O}\right)\right]$ compounds the U-N bond lengths are 2.454(3) $\AA$ and 2.437(4) $\AA$ [15]. As has been previously described for $\left[\mathrm{Et}_{4} \mathrm{~N}\right]_{4}\left[\mathrm{An}(\mathrm{NCS})_{8}\right](\mathrm{An}=\mathrm{Th}$, $\mathrm{U}, \mathrm{Pu}$ [16], the lack of perturbation of the $\pi$-system in the [NCS(e) $]^{-}$ligands suggests no $\pi$-overlap in the U-N bond.

The packing diagram (Figure 2) shows that the structure is a layer type where the cationic components sit between layers of uranyl ions. Hydrogen bonds between the $\mathrm{U}=\mathrm{O}$ and $\mathrm{H}-\mathrm{C}$ of the cations link these layers $\left(\mathrm{d}_{\mathrm{C} \ldots \mathrm{O}}=3.175-3.300 \AA\right)$, as now commonly observed [17]. There are also number of Se...H-C short contacts. The most recent IUPAC definition of a hydrogen bond states that "in most cases, the distance between $H$ and $Y$ are found to be less than the sum of their van der Waals

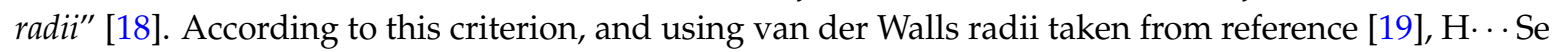
distances of less than $3.02 \AA$ are classed as hydrogen bonds. These form a link between the layers via a C-H of an ethyl group and a Se atom in the coordinated and non-coordinated [NCSe] anion $\left(\mathrm{d}_{\mathrm{C}} \cdots \mathrm{Se}\right.$ $\left.=3.687(16)-3.856(10) ; \mathrm{C}-\mathrm{H} \cdots \mathrm{Se}=142^{\circ}-155^{\circ}\right)$ [20]. Also present in the structure are close contacts between a coordinated selenium atom and the selenium of the non-coordinated [NCSe] $]^{-}(3.427(1) \AA)$ that are shorter than the van der Waals radii (3.64 $\AA$ ) [19]. Chalcogen-chalcogen interactions have been studied both experimentally [21,22], and in the case of [NCS ${ }^{-}$also for uranyl (S . . S = 3.536(2) $\AA$ ) [15], and theoretically [23,24]. This may explain the difficulty in growing single crystals of $\mathbf{1}$ as these weak interactions may be important. Further studies are underway in our laboratory and will be reported on in due course. 


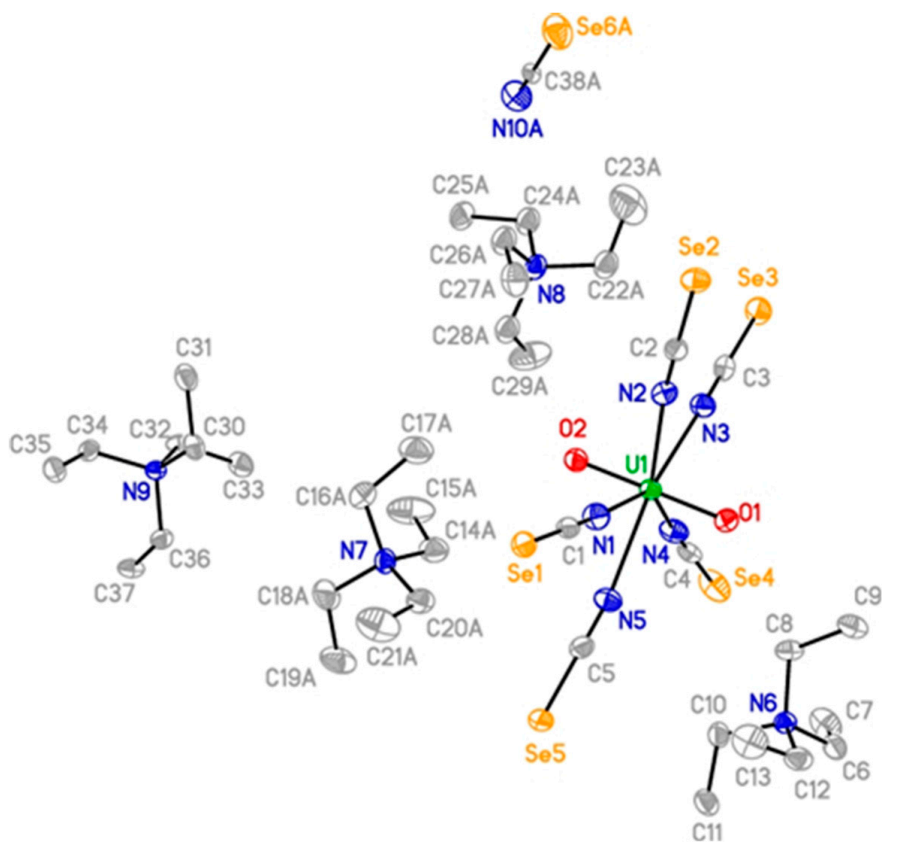

Figure 1. ORTEP plot of the structure of 2 refined with 70; 65; 55\% occupancy for C14a-C21a; C22a-C29a; N10a-Se6a respectively. Thermal displacement shown at 50\% occupancy and hydrogen atoms omitted for clarity. Selected bond lengths $(\AA)$ : $\mathrm{U}(1)-\mathrm{O}(1)$ : $1.771(2) ; \mathrm{U}(1)-\mathrm{N}(1)$ : $2.448(3) ; \mathrm{U}(1)-\mathrm{N}(2)$ : 2.466(3); $\mathrm{U}(1)-\mathrm{N}(3)$ : 2.474(3); $\mathrm{U}(1)-\mathrm{N}(4)$ : 2.440(2); $\mathrm{U}(1)-\mathrm{N}(5): 2.468(3) ; \mathrm{N}(1)-\mathrm{C}(1)$ : $1.158(4) ; \mathrm{N}(2)-\mathrm{C}(2)$ : 1.161(5); N(3)-C(3): 1.154(5); N(4)-C(4): 1.120(5); N(5)-C(5): 1.151(6); C(1)-Se(1): 1.791(3); C(2)-Se(2): 1.782(4); C(3)-Se(3): 1.798(4); C(4)-Se(4): 1.805(4); C(5)-Se(5): 1.794(4); N(10a)-C(38a): 1.081(14); C(38a)-Se(6a): 1.846(7).

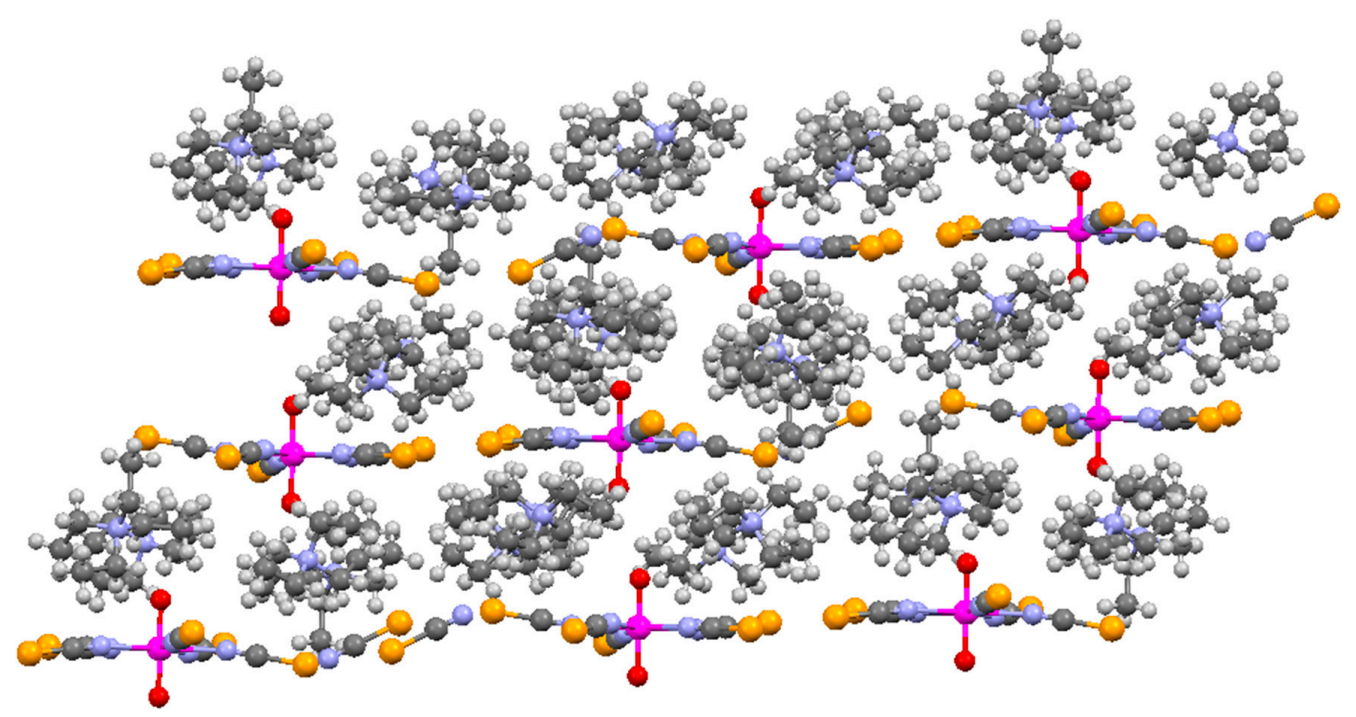

Figure 2. Packing diagram of 2 viewed down the $a$ axis. Color code: $\mathrm{U}$-pink; N—blue; C-Grey; $\mathrm{S}-$ yellow; O-red.

$\mathbf{1}$ has been spectroscopically characterized, whilst for $\mathbf{2}$ there was not enough material. The uranyl group has characteristic vibrations in both the infrared and Raman spectra (Figures S2 and S3). For 1 these bands occur at $921 \mathrm{~cm}^{-1}$ (IR) and $845 \mathrm{~cm}^{-1}$ (R) comparable to the thiocyanate analogue 924 (IR) and $849 \mathrm{~cm}^{-1}$ (R) respectively. The $\mathrm{N}=\mathrm{C}$ stretching frequency at $2056 \mathrm{~cm}^{-1}$ (IR) and 2051, 2060, $2091 \mathrm{~cm}^{-1}$ (R) are also similar to the NCS compound [2063 $\mathrm{cm}^{-1}$ (IR) and 2088, 2058, 2044 
$\mathrm{cm}^{-1}(\mathrm{R})$ ] [11], whilst the C=Se stretch of 1 is visible in the Raman spectrum at 635 and $672 \mathrm{~cm}^{-1}$. ${ }^{1} \mathrm{H}$ NMR spectroscopy was uninformative (Figure S4). ${ }^{13} \mathrm{C}\left\{{ }^{1} \mathrm{H}\right\}$ NMR spectroscopy shows the resonance attributable to the selenocyanate at $117.4 \mathrm{ppm}$ whilst a single peak is observed at $-342.4 \mathrm{ppm}$ in the ${ }^{77} \mathrm{Se}\left\{{ }^{1} \mathrm{H}\right\}$ NMR spectrum. For comparison, in our hands these peaks occur in K[NCSe] at 119.2 and $-314.2 \mathrm{ppm}$ respectively. Therefore, on the basis of the metric parameters from the X-ray structure, vibrational and NMR spectroscopic data we suggest that the bonding in these compounds are ionic with little perturbation of the [NCSe] $]^{-}$anionic fragment upon coordination. Our recent theoretical study of the [NCS] ${ }^{-}$compound suggested a predominantly ionic interaction [11].

The photophysics of this compound has also been investigated (Figure 3). The electronic absorption spectrum of $\mathbf{1}$ (Figure 3a) shows a broad featureless band at $320 \mathrm{~nm}\left(\varepsilon=1,132 \mathrm{~mol}^{-1} \cdot \mathrm{cm}^{-1}\right)$ assigned to transitions due to the [NCSe] ${ }^{-}$fragment and a weak vibronically coupled band at $460 \mathrm{~nm}$ $\left(\varepsilon \sim 100 \mathrm{~mol}^{-1} \cdot \mathrm{cm}^{-1}\right)$ due to the LMCT uranyl band. Excitation at $340 \mathrm{~nm}$ gives an emission spectrum typical for a uranyl moiety (Figure 3b). Pertinent properties are recorded in Table 1, along with a comparison for the uranyl thiocyanate and other pseudohalides. The average vibronic progression of the emission bands are coupled to the Raman active vibrational modes, which at $861 \mathrm{~cm}^{-1}$ is in close agreement with that measured in the Raman spectrum $\left(849 \mathrm{~cm}^{-1}\right)$. The individual spacing $\left(828,868\right.$ and $\left.888 \mathrm{~cm}^{-1}\right)$ reflect the transition of the vibronic parabola from harmonic to anharmonic. The luminescence lifetime of $\mathbf{1}$ was determined by the correlated single photon counting on the microsecond scale following excitation at $372 \mathrm{~nm}$ with a nanoLED (Table 1). The kinetic decay profile was fitted to a mono-exponential decay and the luminescence lifetime for $\mathbf{1}$ was measured to be $1.30 \pm 0.02 \mu \mathrm{s}$. No significant change in lifetime was observed for the different pseudohalide systems given in Table 1. Given the ionicity of the $\mathrm{U}-\mathrm{N}$ bond, ligand exchange processes may be faster than the lifetime of the uranyl excited state and so contributes to the shorter lifetime [25].

(a)

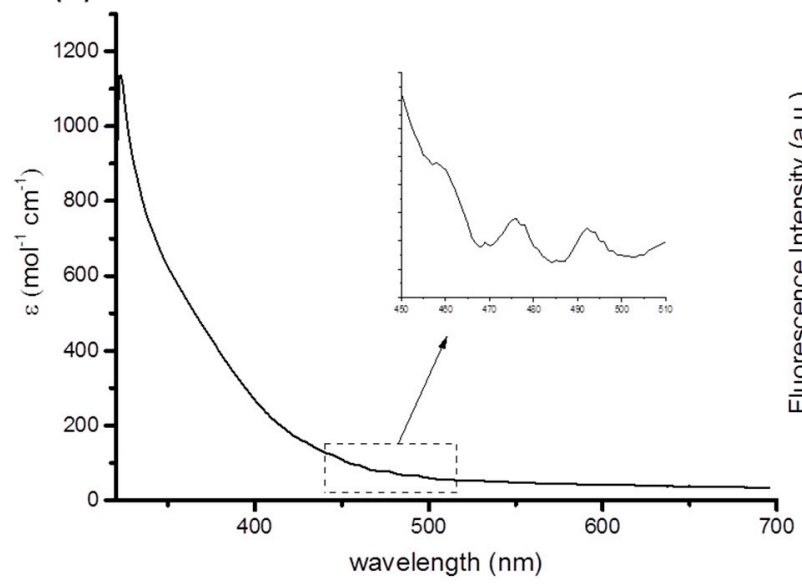

(b)

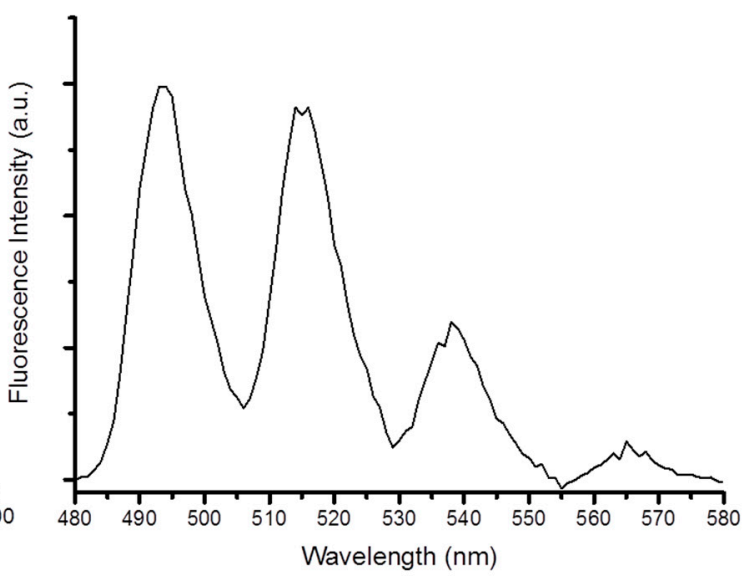

Figure 3. (a) UV-Vis absorption spectrum of $\mathbf{1}$ in acetone; (b) emission spectrum of $\mathbf{1}$ in acetone $\left(\lambda_{\mathrm{ex}}=340 \mathrm{~nm}\right)$.

Table 1. Comparison of photophysical properties of selected uranyl halides and pseudohalides.

\begin{tabular}{ccccccc}
\hline Compound (Solvent) & $\lambda_{\text {abs }} \mathbf{U}=\mathbf{O}(\mathbf{n m})$ & $\lambda_{\mathbf{e m}}(\mathbf{n m})$ & $\mathbf{E}_{0-0}\left(\mathbf{c m}^{-1}\right)$ & $\tau(\mu \mathbf{s})$ & $\chi^{2}$ & Ref. \\
\hline $\mathbf{1}(\mathrm{MeCN})$ & 460 & 514 & 20,267 & 1.30 & 1.40 & This work \\
{$\left[\mathrm{Et}_{4} \mathrm{~N}_{3}\left[\mathrm{UO}_{2}(\mathrm{NCS})_{5}\right](\mathrm{MeCN})\right.$} & 440 & 520 & 20,072 & 1.40 & 1.02 & {$[11]$} \\
{$\left[\mathrm{UO}_{2} \mathrm{Cl}_{2}(\mathrm{OPPh})_{2}\right](\mathrm{MeCN})$} & 440 & 515 & 20,325 & 1.08 & 1.07 & {$[8]$} \\
{$\left[\mathrm{UO}_{2} \mathrm{Cl}_{4}\right]^{2-}\left(\mathrm{MeBu}_{3} \mathrm{~N}\left[\mathrm{Tf}_{2} \mathrm{~N}\right]\right)$} & & 509 & 20,329 & 0.7 & & {$[26]$} \\
\hline
\end{tabular}

We have also briefly examined the electrochemistry of $\mathbf{1}$ (Figure 4). Cyclic voltammetry of a solution of 1 in acetonitrile containing $0.1 \mathrm{M}\left[{ }^{n} \mathrm{Bu}_{4} \mathrm{~N}\right]\left[\mathrm{BPh}_{4}\right]$ shows an irreversible cathodic wave 
at $E_{\mathrm{p}, \mathrm{c}}=-0.95 \mathrm{~V}$ (vs. $\mathrm{Fc} / \mathrm{Fc}^{+}$) ascribed to the unstable $\left[\mathrm{UO}_{2}\right]^{2+} /\left[\mathrm{UO}_{2}\right]^{+}$redox couple, in line with known formal redox potentials of $\mathrm{U}(\mathrm{VI}) / \mathrm{U}(\mathrm{V})$ reduction. For comparison the uranyl [NCS] ${ }^{-}$ analogue displayed the reduction at $-1.45 \mathrm{~V}$ [11]. The putative $1 \mathrm{e}^{-}$reduced uranyl(V) species $\left[\mathrm{Et}_{4} \mathrm{~N}\right]_{4}\left[\mathrm{UO}_{2}(\mathrm{NCSe})_{5}\right]$ would be predicted to be quite unstable as it is now established that good $\pi$-donors and/or sterically bulky groups in the equatorial plane are required for stabilization of this unusual oxidation state $[27,28]$; although, there is evidence for the kinetic stabilization of the $\left[\mathrm{UO}_{2}\right]^{+}$ ion in ionic liquids [29-31]. Any instability would manifest itself in an irreversible reduction, which is indeed what is observed. Also observed in this voltammogram is a broad, poorly defined irreversible oxidation at $E_{\mathrm{p}, \mathrm{a}}=+0.09 \mathrm{~V}\left(v \mathrm{~s}\right.$. $\mathrm{Fc} / \mathrm{Fc}^{+}$) which is not observed at low scan rates, indicating the instability of this species. Given that the metal is in its highest oxidation state, it can be assigned as ligand based; we have observed similar behavior in the uranyl thiocyanate analogue $\left(E_{\mathrm{p}, \mathrm{a}}=+0.30 \mathrm{~V}\right.$ vs. $\mathrm{Fc} / \mathrm{Fc}^{+}$) and extends the family of uranyl coordinated to redox non-innocent ligands [11,32].

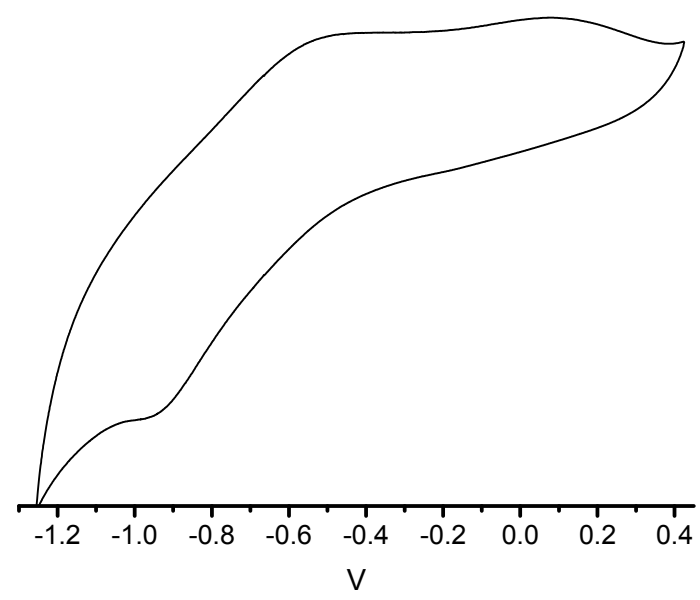

Figure 4. Cyclic Voltammogram of [1] vs. $\mathrm{FC}_{\mathrm{F}} / \mathrm{FC}^{+}$in $\mathrm{MeCN}$ at $293 \mathrm{~K}$, with $0.1 \mathrm{M}\left[\mathrm{Bu}_{4} \mathrm{~N}\right]\left[\mathrm{BPh}_{4}\right]$ as a supporting electrolyte (scan rate $\left.=0.1 \mathrm{~V} \cdot \mathrm{s}^{-1}\right)$.

\section{Experimental Section}

Caution! Although depleted uranium was used during the course of the experimental work, as well as the radiological hazards uranium is a toxic metal and care should be taken with all manipulations. Experiments were carried out using pre-set radiological safety precautions in accordance with the local rules of Trinity College Dublin.

${ }^{1} \mathrm{H},{ }^{13} \mathrm{C}\left\{{ }^{1} \mathrm{H}\right\}$ and ${ }^{77} \mathrm{Se}\left\{{ }^{1} \mathrm{H}\right\}$ NMR spectra were recorded on an AV400 spectrometer (Bruker, Karlsruhe, Germany) operating at 400.23, 155.54 and $76.33 \mathrm{MHz}$ respectively, and were referenced to the residual ${ }^{1} \mathrm{H}$ resonances of the solvent used or external $\mathrm{Me}_{2} \mathrm{Se}$. IR spectra were recorded on a Spectrum One spectrometer (Perkin Elmer, Norwalk, CT, USA) with attenuated total reflectance (ATR) accessory. Raman spectra were obtained using 785-nm excitation on a 1000 micro-Raman system (Renishaw, Wotton-under-Edge, UK) in sealed capillaries. X-ray crystallography data were measured on an Apex diffractometer (Bruker). The structures were solved by direct methods and refined on F2 by full matrix least squares (SHELX97) using all unique data. CCDC 1424467 contains the supplementary crystallographic data for this paper. This data can be obtained free of charge from The Cambridge Crystallographic Data Centre via www.ccdc.cam.ac.uk/data_request/cif. UV-Vis measurements were made on a Lambda 1050 spectrophotometer (Perkin Elmer USA), using fused silica cells with a path length of $1 \mathrm{~cm}$. Steady-state photoluminescence spectra were recorded on a Fluorolog-3 spectrofluorimeter (Horiba-Jobin-Yvon, Stanmore, UK). Luminescence lifetime data were recorded following $372 \mathrm{~nm}$ excitation, using time-correlated single-photon counting (a PCS900 plug-in PC card for fast photon counting). Lifetimes were obtained by tail fit on the data obtained, and the quality of fit was judged by minimization of reduced chi-squared and residuals squared. 
Cyclic voltammetry measurements were conducted in a standard three-electrode cell using a high performance digital potentiostat (CH model $1760 \mathrm{D}$ Bi-potentiostat system monitored using CH1760D electrochemical workstation beta software). All solutions were degassed for 15 min before commencing analysis. A platinum electrode with a diameter of $2 \mathrm{~mm}$ was employed as the working electrode, a platinum rod (together with internal referencing $v s . \mathrm{Fc} / \mathrm{Fc}^{+}$) was used as a reference electrode and a platinum wire electrode as counter electrode. The electrolyte was a solution of $0.1 \mathrm{M}\left[{ }^{n} \mathrm{Bu}_{4} \mathrm{~N}\right]\left[\mathrm{BPh} \mathrm{C}_{4}\right]$ in $\mathrm{CH}_{3} \mathrm{CN}$. $\left[\mathrm{UO}_{2} \mathrm{Cl}_{2}(\mathrm{THF})_{3}\right]$ was prepared via the literature procedure [33] whilst all other reagents and solvents were obtained from commercial sources.

\section{Synthesis of $\mathbf{1}$}

Method 1. To a solution of $\mathrm{UO}_{2}\left(\mathrm{NO}_{3}\right)_{2} \cdot 6 \mathrm{H}_{2} \mathrm{O}(400 \mathrm{mg}, 0.80 \mathrm{mmol})$ in acetonitrile $\left(30 \mathrm{~cm}^{3}\right)$ were added KNCSe $(576 \mathrm{mg}, 4.0 \mathrm{mmol})$ and $\mathrm{Et}_{4} \mathrm{NCl}(328 \mathrm{mg}, 2.4 \mathrm{mmol})$. The solution mixture was stirred at room temperature for $60 \mathrm{~min}$. The resulting orange solution was filtered and the solvent was reduced in volume. After $48 \mathrm{~h}$ at room temperature, the orange solution deposited orange-yellow crystals suitable for X-ray diffraction ( $408 \mathrm{mg}, 0.34 \mathrm{mmol}$, yield $=43 \%$ ).

Method 2. Under an atmosphere of high purity dry argon, to a solution of $\mathrm{UO}_{2} \mathrm{Cl}_{2} \mathrm{THF}_{3}(50 \mathrm{mg}$, $0.090 \mathrm{mmol})$ in dry THF $\left(20 \mathrm{~cm}^{3}\right)$ were added sequentially KNCSe $(65 \mathrm{mg}, 0.45 \mathrm{mmol})$ and $\mathrm{Et}_{4} \mathrm{NCl}$ (45 mg, $0.27 \mathrm{mmol}$ ). The solution was stirred at room temperature for $60 \mathrm{~min}$. The resulting orange solution was filtered and the solvent was reduced in volume. Placement at $-20{ }^{\circ} \mathrm{C}$ overnight yielded an orange powder (33 $\mathrm{mg}, 0.036 \mathrm{mmol}$, yield $=40 \%$ ).

IR $\left(v / \mathrm{cm}^{-1}\right): 784(\mathrm{C}=\mathrm{Se}), 921(\mathrm{U}=\mathrm{O}), 2056(\mathrm{C}=\mathrm{N})$; $\operatorname{Raman}\left(v / \mathrm{cm}^{-1}\right): 635$ and $672(\mathrm{C}=\mathrm{Se}), 845$ $(\mathrm{U}=\mathrm{O}), 2051,2060$ and $2091(\mathrm{C}=\mathrm{N}) ; \delta_{\mathrm{H}}\left(\mathrm{CD}_{3} \mathrm{CN} / \mathrm{ppm}\right): 3.21\left(\mathrm{q}, 2 \mathrm{H},{ }^{3} \mathrm{~J}_{\mathrm{H}-\mathrm{H}}=7.28 \mathrm{~Hz}, \mathrm{CH}_{2}\right), 1.25(\mathrm{t}, 3 \mathrm{H}$, $\left.{ }^{3} \mathrm{~J}_{\mathrm{H}-\mathrm{H}}=7.32 \mathrm{~Hz}, \mathrm{CH}_{3}\right) ; \delta_{\mathrm{C}}\left(\mathrm{CD}_{3} \mathrm{CN} / \mathrm{ppm}\right): 117.4(\mathrm{~N}=\mathrm{C}=\mathrm{Se}), 29.9\left(\mathrm{CH}_{2}\right), 6.8\left(\mathrm{CH}_{3}\right) ; \delta_{\mathrm{Se}}\left(\mathrm{d}-\mathrm{CH}_{3} \mathrm{CN} / \mathrm{ppm}\right)$ : $-342.2(\mathrm{~N}=\mathrm{C}=\mathrm{Se})$.

\section{Conclusions}

To summarize, we have prepared and structurally characterized the first uranyl complexes of a selenocyanate ligand, which feature some unusual Se $\cdots$ Se chalcogenide interactions and Se $\cdots H-C$ hydrogen bonding. Vibrational and structural data suggest that the $\mathrm{U}-\mathrm{N}$ bond is ionic and there is little perturbation of the [NCSe] $^{-}$fragment compared to K[NCSe]. A photophysical investigation has shown that there is a small shift in the positions of the bands compared to the analogous $\left[\mathrm{UO}_{2}(\mathrm{NCS})_{5}\right]^{3-}$ compound and the lifetime of the emission does not vary significantly with the nature of the pseudohalide. Finally, an electrochemical investigation revealed that the putative uranyl(V) compound is unstable with respect to disproportionation whilst there is a ligand based oxidation, similar to that observed in the $\left[\mathrm{UO}_{2}(\mathrm{NCS})_{5}\right]^{3-}$ analogue.

Supplementary Materials: Supplementary materials can be accessed at www.mdpi.com/2304-6740/4/1/4/s1.

Acknowledgments: We thank Trinity College Dublin for funding this work.

Author Contributions: Steffano Nuzzo conducted the synthesis and data analysis, Brendan Twamley conducted the X-ray crystallography, Michelle P. Browne and Michael E. G. Lyons did the electrochemistry measurements, Robert J. Baker conceived the experiments and wrote the manuscript.

Conflicts of Interest: The authors declare no conflict of interest.

\section{References}

1. Günther, R.T.; Manley, J.J. A mural glass mosaic from the Imperial Roman Villa near Naples. Archaeologia 1912, 63, 99-108. [CrossRef]

2. Denning, R.G. Electronic structure and bonding in actinyl ions and their analogs. J. Phys. Chem. A 2007, 111, 4125-4143. [CrossRef] [PubMed]

3. Liddle, S.T. The renaissance of non-aqueous uranium chemistry. Angew. Chem. Int. Ed. 2015, 54, 8604-8641. [CrossRef] [PubMed] 
4. Jones, M.B.; Gaunt, A.J. Recent developments in synthesis and structural chemistry of nonaqueous actinide complexes. Chem. Rev. 2013, 113, 1137-1198. [CrossRef] [PubMed]

5. Baker, R.J. New reactivity of the uranyl ion. Chem. Eur. J. 2012, 18, 16258-16271. [CrossRef] [PubMed]

6. Natrajan, L.S. Developments in the photophysics and photochemistry of actinide ions and their coordination compounds. Coord. Chem. Rev. 2012, 256, 1583-1603. [CrossRef]

7. Drobot, B.; Steudtner, R.; Raff, J.; Geipel, G.; Brendler, V.; Tsushima, S. Combining luminescence spectroscopy, parallel factor analysis and quantum chemistry to reveal metal speciation-A case study of uranyl(VI) hydrolysis. Chem. Sci. 2015, 6, 964-972. [CrossRef]

8. Hashem, E.; McCabe, T.; Schulzke, C.; Baker, R.J. Synthesis, structure and photophysical properties of $\left[\mathrm{UO}_{2} \mathrm{X}_{2}\left(\mathrm{O}=\mathrm{PPh}_{3}\right)_{2}\right](\mathrm{X}=\mathrm{Cl}, \mathrm{Br}, \mathrm{I})$. Dalton Trans. 2014, 43, 1125-1131. [CrossRef] [PubMed]

9. Redmond, M.P.; Cornet, S.M.; Woodall, S.D.; Whittaker, D.; Collison, D.; Helliwell, M.; Natrajan, L.S. Probing the local coordination environment and nuclearity of uranyl(VI) complexes in non-aqueous media by emission spectroscopy. Dalton Trans. 2011, 40, 3914-3926. [CrossRef] [PubMed]

10. Aoyagi, N.; Shimojo, K.; Brooks, N.R.; Nagaishi, R.; Naganawa, H.; van Hecke, K.; van Meervelt, L.; Binnemans, K.; Kimura, T. Thermochromic properties of low-melting ionic uranyl isothiocyanate complexes. Chem. Commun. 2011, 47, 4490-4492. [CrossRef] [PubMed]

11. Hashem, E.; Platts, J.A.; Hartl, F.; Lorusso, G.; Evangelisti, M.; Schulzke, C.; Baker, R.J. Thiocyanate complexes of uranium in multiple oxidation states: A combined structural, magnetic, spectroscopic, spectroelectrochemical, and theoretical study. Inorg. Chem. 2014, 53, 8624-8637. [CrossRef] [PubMed]

12. Crawford, M.-J.; Karaghiosoff, K.; Mayer, P. The homoleptic U(NCSe $)_{8}{ }^{4-}$ anion in $\left(\mathrm{Pr}_{4} \mathrm{~N}\right)_{4} \mathrm{U}(\mathrm{NCSe})_{8} \cdot 2 \mathrm{CFCl}{ }_{3}$ and $\mathrm{Th}(\mathrm{NCSe})_{4}\left(\mathrm{OP}\left(\mathrm{NMe}_{2}\right)_{3}\right)_{4} \cdot 0.5 \mathrm{CH}_{3} \mathrm{CN} \cdot 0.5 \mathrm{H}_{2} \mathrm{O}$ : First structurally characterized actinide isoselenocyanates. Z. Anorg. Allg. Chem. 2010, 636, 1903-1906. [CrossRef]

13. Rowland, C.E.; Kanatzidis, M.G.; Soderholm, L. Tetraalkylammonium uranyl isothiocyanates. Inorg. Chem. 2012, 51, 11798-11804. [CrossRef] [PubMed]

14. Straka, M.; Patzschke, M.; Pyykkö, P. Why are hexavalent uranium cyanides rare while U-F and U-O bonds are common and short? Theor. Chem. Acc. 2003, 109, 332-340. [CrossRef]

15. Surbella, R.G.; Cahill, C.L. The exploration of supramolecular interactions stemming from the $\left[\mathrm{UO}_{2}(\mathrm{NCS})_{4}\left(\mathrm{H}_{2} \mathrm{O}\right)\right]^{2-}$ tecton and substituted pyridinium cations. CrystEngComm 2014, 16, 2352-2364. [CrossRef]

16. Carter, T.J.; Wilson, R.E. Coordination chemistry of homoleptic actinide(IV)-thiocyanate complexes. Chem. Eur. J. 2015, 21, 15575-15582. [CrossRef] [PubMed]

17. Fortier, S.; Hayton, T.W. Oxo ligand functionalization in the uranyl ion $\left(\mathrm{UO}_{2}{ }^{2+}\right)$. Coord. Chem. Rev. 2010, 254, 197-214. [CrossRef]

18. Arunan, E.; Desiraju, G.R.; Klein, R.A.; Sadlej, J.; Scheiner, S.; Alkorta, I.; Clary, D.C.; Crabtree, R.H.; Dannenberg, J.J.; Hobza, P.; et al. Definition of the hydrogen bond (IUPAC Recommendations 2011). J. Pure Appl. Chem. 2011, 83, 1637-1641. [CrossRef]

19. Alvarez, S. A cartography of the van der Waals territories. Dalton Trans. 2013, 42, 8617-8636. [CrossRef] [PubMed]

20. Michalczyk, R.; Schmidt, J.G.; Moody, E.; Li, Z.; Wu, R.; Dunlap, R.B.; Odom, J.D.; Silks, L.A., III. Unusual $\mathrm{C}-\mathrm{H} \cdots \mathrm{Se}=\mathrm{C}$ interactions in aldols of chiral $\mathrm{N}$-acyl selones detected by gradient-selected ${ }^{1} \mathrm{H}-{ }^{77}$ Se HMQC NMR spectroscopy and X-ray crystallography. Angew. Chem. Int. Ed. 2000, 39, 3067-3070. [CrossRef]

21. Uhl, W.; Wegener, P.; Layh, M.; Hepp, A.; Wuerthwein, E.-U. Chalcogen capture by an Al/P-based frustrated lewis pair: Formation of Al-E-P bridges and intermolecular tellurium-tellurium interactions. Organometallics 2015, 34, 2455-2462. [CrossRef]

22. Kobayashi, K.; Masu, H.; Shuto, A.; Yamaguchi, K. Control of face-to-face $\pi-\pi$ stacked packing arrangement of anthracene rings via chalcogen-chalcogen interaction: 9,10-Bis(methylchalcogeno)anthracenes. Chem. Mater. 2005, 17, 6666-6673. [CrossRef]

23. Bleiholder, C.; Gleiter, R.; Werz, D.B.; Koeppel, H. Theoretical investigations on heteronuclear chalcogen-chalcogen interactions: On the nature of weak bonds between chalcogen centers. Inorg. Chem. 2007, 46, 2249-2260. [CrossRef] [PubMed]

24. Bleiholder, C.; Werz, D.B.; Koeppel, H.; Gleiter, R. Theoretical investigations on chalcogen-chalcogen interactions: What makes these nonbonded interactions bonding? J. Am. Chem. Soc. 2006, 128, 2666-2674. [CrossRef] [PubMed] 
25. Fazekas, Z.; Yamamura, T.; Tomiyasu, H. Deactivation and luminescence lifetimes of excited uranyl ion and its fluoro complexes. J. Alloys Compd. 1998, 271-273, 756-759. [CrossRef]

26. Sornein, M.-O.; Cannes, C.; le Naour, C.; Lagarde, G.; Simoni, E.; Berthet, J.-C. Uranyl complexation by chloride ions. Formation of a tetrachlorouranium(VI) complex in room temperature ionic liquids [Bmim] $\left[\mathrm{Tf}_{2} \mathrm{~N}\right]$ and $\left[\mathrm{MeBu}_{3} \mathrm{~N}\right]\left[\mathrm{Tf}_{2} \mathrm{~N}\right]$. Inorg. Chem. 2006, 45, 10419-10421. [CrossRef] [PubMed]

27. Hardwick, H.C.; Royal, D.S.; Helliwell, M.; Pope, S.J.A.; Ashton, L.; Goodacre, R.; Sharrad, C.A. Structural, spectroscopic and redox properties of uranyl complexes with a maleonitrile containing ligand. Dalton Trans. 2011, 40, 5939-5952. [CrossRef] [PubMed]

28. Clark, D.L.; Conradson, S.D.; Donohoe, R.J.; Keogh, D.W.; Morris, D.E.; Palmer, P.D.; Rogers, R.D.; Tait, C.D. Chemical speciation of the uranyl ion under highly alkaline conditions. Synthesis, structures, and oxo ligand exchange dynamics. Inorg. Chem. 1999, 38, 1456-1466. [CrossRef]

29. Yaprak, D.; Spielberg, E.T.; Bäcker, T.; Richter, M.; Mallick, B.; Klein, A.; Mudring, A.-V. A roadmap to uranium ionic liquids: Anti-crystal engineering. Chem. Eur. J. 2014, 20, 6482-6493. [CrossRef] [PubMed]

30. Ogura, T.; Takao, K.; Sasaki, K.; Arai, T.; Ikeda, Y. Spectroelectrochemical identification of a pentavalent uranyl tetrachloro complex in room-temperature ionic liquid. Inorg. Chem. 2011, 50, 10525-10527. [CrossRef] [PubMed]

31. Ikeda, Y.; Hiroe, K.; Asanuma, N.; Shirai, A. Electrochemical studies on uranyl(VI) chloride complexes in ionic liquid, 1-butyl-3-methylimidazolium chloride. J. Nucl. Sci. Technol. 2009, 46, 158-162. [CrossRef]

32. Takao, K.; Tsushima, S.; Ogura, T.; Tsubomura, T.; Ikeda, Y. Experimental and theoretical approaches to redox innocence of ligands in uranyl complexes: What is formal oxidation state of uranium in reductant of uranyl(VI)? Inorg. Chem. 2014, 53, 5772-5780. [CrossRef] [PubMed]

33. Wilkerson, M.P.; Burns, C.J.; Paine, R.T.; Scott, B.L. Synthesis and crystal structure of $\mathrm{UO}_{2} \mathrm{Cl}_{2}(\mathrm{THF})_{3}$ : A simple preparation of an anhydrous uranyl reagent. Inorg. Chem. 1999, 38, 4156-4158. [CrossRef]

(C) 2016 by the authors; licensee MDPI, Basel, Switzerland. This article is an open access article distributed under the terms and conditions of the Creative Commons by Attribution (CC-BY) license (http://creativecommons.org/licenses/by/4.0/). 